\title{
How can we restore biodiversity and ecosystem services in mining and industrial sites?
}

\author{
Karel Prach ${ }^{1,2}$ • Anne Tolvanen ${ }^{3,4}$ \\ Received: 14 June 2016 / Accepted: 19 June 2016 / Published online: 4 July 2016 \\ (C) Springer-Verlag Berlin Heidelberg 2016
}

\section{Introduction}

Restoration of ecosystems on post-mining and post-industrial sites represents an important part of contemporary restoration ecology. Over the globe, about $1 \%$ of land surface was directly influenced by mining activities (Walker 1999) and if we include various post-industrial sites, such as, for example, ash and other waste deposits, the figure may increase. Mining is known to have dramatic environmental impacts. Besides that it strongly degrades or destroys natural ecosystems, the impacts may be reflected to human health, e.g., through the contamination of water and air (Palmer et al. 2010). Restoration and reclamation of post-mining and postindustrial sites aim at mitigating the adverse impacts of mining on the environment and human health. Regeneration is, however, a long process, as affected ecosystems have lost their biodiversity and most of their ecosystem functions and services. Several approaches and measures are therefore used to bring back the lost ecosystems or to replace them by

Responsible editor: Philippe Garrigues

Karel Prach

prach@prf.jcu.cz

Anne Tolvanen

anne.tolvanen@luke.fi

1 Department of Botany, Faculty of Science, USB, Branišovská 1760, CZ-370 05 České Budějovice, Czech Republic

2 Institute of Botany, Czech Academy of Sciences, Dukelská 135, CZ-379 82 Třeboň, Czech Republic

3 Natural Resources Institute Finland, University of Oulu, P.O. Box 413, FI-90014 Oulu, Finland

4 Department of Ecology, University of Oulu, P.O. Box 413, FI-90014 Oulu, Finland alternative ecosystems that withstand the degraded conditions (Bradshaw 2000).

Restoration of biodiversity and ecosystem services in postmining and post-industrial sites has received wide attention among restoration scientists. The 9th European Conference on Ecological Restoration (SER 2014) held in Oulu, Finland, on August 2014, was not an exception. Almost 400 participants from 36 countries from science, EU policy, management, private companies, consultancy firms, and NGOs gathered together to discuss the integration of ecosystem service and land use questions to the context of ecological restoration. Many papers in this volume were presented in the conference session "Mineral extraction sites: restoring biodiversity and ecosystem services" where in a total of 12 oral presentations and five posters were shown. By collecting an edited selection of SER2014 conference presentations and other selected papers, this special issue provides an overview and appraisal on how the biodiversity and ecosystem services concepts have been incorporated into the restoration and reclamation of post-mining and post-industrial sites.

\section{Biodiversity and ecosystem services}

Ecological restoration aims at increasing the biodiversity and ecosystem functions or services (Whisenant 1999; Farber et al. 2006). Ecosystem services targeted initially in post-mining and post-industrial sites are related to soil physical characteristics, such as erosion control, water filtration, and the improvement of the micro- and mesoclimate, which are prerequisites for the establishment of permanent vegetation. Thereafter, the target services can be the re-establishment of productive sites, carbon sequestration, and the increase of the aesthetic value of the site or the landscape. Ecologists preferably emphasize the reestablishment or increase of biodiversity as a goal of restoration. 
Because biodiversity is seen to be associated with the increase in ecosystem functions or ecosystem services (Rey Benayas et al. 2008), it is commonly used as a core criterion or as a surrogate of ecosystem "health." The term biodiversity can be understood as the diversity of species, functional groups, food webs, or genetic structure of populations (Gaston and Spicer 2004). Although species diversity is a useful and often easily measured criterion in restoration projects, it may be insufficient and even misleading in some cases. For example, high species diversity may indicate that there are both target species (SER 2004) and competitive generalists, sometimes alien species, at the restored site. The latter may signal an unwanted regeneration pathway (Kopeć et al. 2015). Selecting biodiversity indicators in mining and restoration projects implies making choices based upon values and focusing on some aspects that can be managed (Pitz et al. 2015).

\section{Ecological restoration and reclamation}

Passive restoration (Holl and Aide 2011), also known as spontaneous succession (Prach and Pyšek 2001), forms one end of a continuum of ecological restoration intervention levels (Prach and Hobbs 2008; Holl and Aide 2011; Walker et al. 2014). Passive restoration involves no or few active restoration measures, and the ecosystem is expected to recover principally through natural succession. The other end of the continuum is technical reclamation which is often applied to heavily disturbed sites such as mining and other industrial sites. Technical reclamation involves heavy interventions such as the restructuring of landforms, importing soil, and planting or sowing of plants. The target ecosystem may not always be the original ecosystem lost by mining or industrial activities, but a system that is considered useful for some purpose (SER 2004), for example forest management (Metslaid et al. 2015). Intermediate interventions are called assisted restoration and may include an ecologically justified enhancement of abiotic site conditions, the suppression of undesirable species, planting or sowing target species, and creating microsite heterogeneity. At mining and industrial sites, assisted restoration aims at speeding up the natural regeneration of the ecosystem, which might otherwise be very slow, for example, due to adverse (cold, dry, wet, nutrient poor, polluted) conditions.

In the papers of this issue, attention is given to passive restoration and the factors influencing spontaneous succession (e.g., Nikolic et al. 2015; Tropek et al. 2015; Horáčková et al. 2015; Alday et al. 2015), to field experiments comparing ecological restoration measures (Tarvainen and Tolvanen 2015; Karofeld et al. 2015), to the comparison between reclamation and passive restoration (Řehounková et al. 2016; Šebelíková et al. 2015), and to the reclamation by afforestation (Metslaid et al. 2015). Based on the results, passive restoration seems to be an effective approach at many post-mining and post- industrial sites (but see Kopeć et al. 2015), whereas technical reclamation may have negative effects on the biodiversity, since it decreases the amount of habitats for specialized threatened species (Tropek et al. 2015; Řehounková et al. 2016) or maintains the pool of seeded alien species that may spread to the surrounding environment (Rydgren et al. 2015). On the other hand, technical reclamation can be justified through the economic profit as in the case of timber production of afforested sites (Metslaid et al. 2015). Experimentally tested ecological restoration measures (Tarvainen and Tolvanen 2015; Karofeld et al. 2015) and analyses of environmental and plant characteristics influencing the regeneration and succession (Boisson et al. 2015; Alday et al. 2015; Nikolic et al. 2015) provide scientific information that can be used in developing effective ecological restoration under adverse conditions. A special and, in some cases, the only possible restoration measure is the ex situ conservation of endangered species which can be later used in ecological restoration projects (Le Stradic et al. 2015).

\section{What is the restoration target?}

Undisturbed neighboring ecosystems such as forests (Alday et al. 2015; Tarvainen and Tolvanen 2015), peatlands (Karofeld et al. 2015), and the tundra (Rydgren et al. 2015) may be used as a reference for ecological restoration, but they may not always be a valid reference for large-scale mining or industrial sites. An alternative stable state should also be considered (Alday and Marrs 2014). Advanced, late successional ecosystem stages may not always be the target of restoration, as also early successional stages may exhibit a high conservation value for some specialized species (̌̌ehounková et al. 2016; Tropek et al. 2015). Hence, their maintenance can also be a goal of restoration projects. Generally, it is easier to set targets to generalized plant community characteristics, such as total vegetation cover, and the presence of species functional groups than to species composition (Horáčková et al. 2015).

\section{Conclusions and perspectives}

In effort to restore the sites disturbed by mining and industrial activities, restoration projects should involve ecologically suitable and economically viable measures which will produce multiple social and ecological benefits. A challenge is that a general consensus of biodiversity indicators is difficult to reach due to the complexity of the biodiversity concept (Pitz et al. 2015). This may influence the restoration target, which is partially dependent on the values of the stakeholders. Besides the principally perceived negative environmental impacts of mining and industrial sites, post-mining and post-industrial sites are not only negative products of human disturbances. They may provide refugia 
for specialized wildlife (Prach et al. 2011; Heneberg et al. 2013; Mata et al. 2016; Řehounková et al. 2016; Tropek et al. 2015). Unless mining and other industrial activities destroy valuable sites with high natural, historical, or aesthetic value, they may increase, under certain conditions, biodiversity and geodiversity of a landscape. Some examples are given also in this special issue.

Based on the papers presented in this special issue, we can conclude:

- Spontaneous succession (passive restoration) per se often leads to the re-establishment of target ecosystem.

- Natural processes can be assisted to speed up the recovery under adverse environmental conditions.

- Adverse environmental conditions, contamination of the surroundings, or economic reasons may also favor technical reclamation.

- Scientific information on various measures and approaches, and factors influencing the regeneration is a basis for the planning of effective ecological restoration at mining and post-industrial sites.

\section{References}

Alday JG, Marrs RH (2014) A simple test for alternative states in ecological restoration: the use of principal response curves. Appl Veg Sci 17:302-311

Alday JG, Zaldívar P, Torroba-Balmori P, Fernández-Santos B, MartínezRuiz C (2015) Natural forest expansion on reclaimed coal mines in Northern Spain: the role of native shrubs as suitable microsites. Env Sci Poll Res. doi:10.1007/s11356-015-5681-2

Bradshaw A (2000) The use of natural processes in reclamation - advantages and difficulties. Landsc Urban Plan 51:89-100

Boisson S, Le Stradic S, Collignon J, Séleck M, Malaisse F, Ngoy Shutcha M, Faucon M-P, Mahy G (2015) Potential of coppertolerant grasses to implement phytostabilisation strategies on polluted soils in South D. R. Congo. Env Sci Poll Res. doi:10.1007 /s11356-015-5442-2

Farber S, Costanza R, Childers DL, Erickson J, Gross K, Grove M, Hopkinson CS, Kahn J, Pincetl S, Troy A, Warren P, Wilson M (2006) Linking ecology and economics for ecosystem management. Bioscience 56:121-133

Gaston KJ, Spicer JI (2004) Biodiversity: an introduction, 2nd edn. Blackwell, Oxford

Heneberg P, Bogusch P, Řehounek J (2013) Sandpits provide critical refuge for bees and wasps (Hymenoptera: Apocrita). J Insect Conserv 17:473-490

Holl KD, Aide TM (2011) When and where to actively restore ecosystems? For Ecol Manag 261:1558-1563

Horáčková M, Řehounková K, Prach K (2015) Are seed and dispersal characteristics of plants capable of predicting colonization of postmining sites? Env Sci Poll Res. doi:10.1007/s11356-015-5415-5

Karofeld E, Müür M, Vellak K (2015) Factors affecting re-vegetation dynamics of experimentally restored extracted peatland in Estonia. Env Sci Poll Res. doi:10.1007/s11356-015-5396-4

Kopeć D, Woziwoda B, Forysiak J, Sławik L, Ptak A, Charążka E (2015) The use of ALS, botanical, and soil data to monitor the environmental hazards and regeneration capacity of areas devastated by highway construction. Env Sci Poll Res. doi:10.1007/s11356-015-5637-6
Le Stradic S, Séleck M, Lebrun J, Boisson S, Handjila G, Faucon M-P, Enk T, Mahy G (2015) Comparison of translocation methods to conserve metallophyte communities in the Southeastern D.R. Congo. Env Sci Poll Res. doi:10.1007/s11356-015-5548-6

Mata C, Malo JE, Galaz JL, Cadorzo C, Lagunas H (2016) A three step approach to minimize the impact of a mining site on vicuña (Vicugna vicugna) and to restore landscape diversity. Env Sci Poll Res. doi:10.1007/s11356-016-7047-9

Metslaid S, Stanturf JA, Hordo M, Korjus H, Laarmann D, Kiviste A (2015) Response of Scots pine to climatic factors and management on the reclaimed areas of oil shale mining. Env Sci Poll Res. doi:10.1007/s11356-015-5647-4

Nikolic N, Böcker R, Nikolic M (2015) Long-term passive restoration following fluvial deposition of sulphidic copper tailings: nature filters out different solutions. Env Sci Poll Res. doi:10.1007/s11356-015-5205-0

Palmer MA, Bernhardt ES, Schlesinger WH, Eshleman KN, FoufoulaGeorgiou E, Hendryx MS, Lemly AD, Likens GE, Loucks OL, Power ME, White PS, Wilcock PR (2010) Mountaintop mining consequences. Science 327:148-149

Pitz C, Mahy G, Vermeulen C, Marlet C, Séleck M (2015) Developing biodiversity indicators on a stakeholder's opinions basis: the gypsum industry key performance indicators framework. Env Sci Poll Res. doi:10.1007/s11356-015-5269-x

Prach K, Hobbs RJ (2008) Spontaneous succession versus technical reclamation in the restoration of disturbed sites. Restor Ecol 16:363-366

Prach K, Pyšek P (2001) Using spontaneous succession for restoration of human-disturbed habitats: experience from Central Europe. Ecol Eng 17:55-62

Prach K, Řehounková K, Řehounek J, Konvalinková P (2011) Ecological restoration of Central European mining sites: a summary of a multisite analysis. Landsc Res 36:263-268

Řehounková K, Čížek L, Řehounek J, Šebelíková L, Tropek L, Lencová K, Bogusch P, Marhoul P, Máca J (2016) Additional disturbances as a beneficial tool for restoration of post-mining sites: a multi-taxa approach. Env Sci Poll Res. doi:10.1007/s11356-016-6585-5

Rey Benayas JM, Bullock JM, Newton AC (2008) Creating woodland islets to reconcile ecological restoration, conservation, and agricultural land use. Front Ecol Environ 6:329-336

Rydgren K, Auestad I, Norunn HamreL, Hagen D, Rosef L, Skjerdal G (2015) Long-term persistence of seeded grass species: an unwanted side-effect of ecological restoration. Env Sci Poll Res. doi:10.1007 /s11356-015-4161-z

Šebelíková L, Řehounková K, Prach K (2015) Spontaneous revegetation vs. forestry reclamation in post-mining sand pits. Env Sci Poll Res. doi:10.1007/s11356-015-5330-9

SER [Society for Ecological Restoration] (2004) The SER international primer on ecological restoration. Version 2. Society for Ecological Restoration, Tucson

Tarvainen O, Tolvanen A (2015) Healing the wounds in the landscapereclaiming gravel roads in conservation areas. Env Sci Poll Res. doi:10.1007/s11356-015-5341-6

Tropek R, Cerna I, Straka J, Kocarek P, Malenovsky I, Tichanek F, Sebek P (2015) In search for a compromise between biodiversity conservation and human health protection in restoration of fly ash deposits: effect of anti-dust treatments on five groups of arthropods. Env Sci Poll Res. doi:10.1007/s11356-015-4382-1

Walker LR (ed) (1999) Ecosystems of disturbed ground. Ecosystems of the world, vol 16. Elsevier, Amsterdam

Walker LR, Hölzel N, Marrs R, del Moral R, Prach K (2014) Optimization of intervention levels in ecological restoration. Appl Veg Sci 17:187-192

Whisenant S (1999) Repairing damaged wildlands. Cambridge University Press, Cambridge 


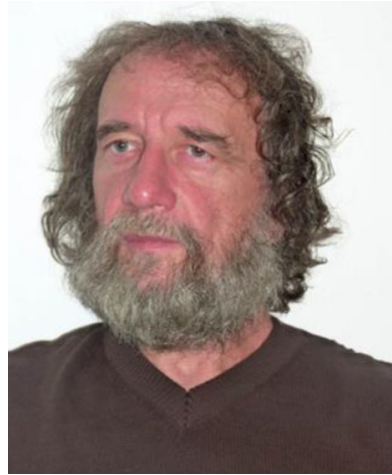

Karel Prach is a full professor at the Faculty of Science, University of České Budějovice, and a senior research scientist at the Institute of Botany, Czech Academy of S c i ences in Tř ebon̆, Czech Republic. He obtained his $\mathrm{PhD}$ in plant ecology from Charles University and Academy of Sciences in Prague in 1983. His research interests are in the areas of vegetation dynamics, invasive ecology, and restoration ecology. His recent research efforts have been directed towards metaanalyses across different successional series, and exploitation of spontaneous or assisted ecological succession in ecological restoration. He is a member of the Society for Ecological Restoration and a member of the European board of the society, a member of the International Association for Vegetation Science, and President of the Czech Botanical Society. He serves as a coordinating editor for the journal Restoration Ecology and is a member of editorial boards of several other international journals. Up to now, he has published about 300 papers on various topics of plant ecology (111 registered in the Web of Science), especially on succession, restoration ecology, ecology of invasive alien plants, and ecology of river floodplains; he co-authored or co-edited three monographs and ten proceedings.

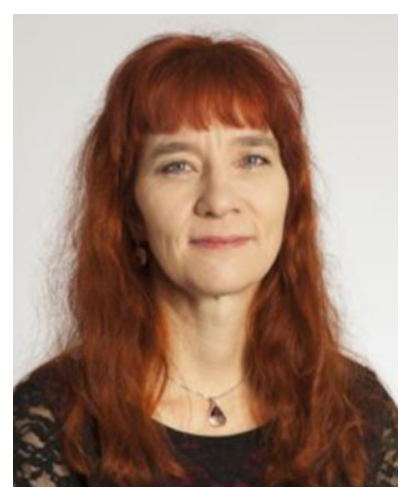

Anne Tolvanen holds a professorship in forest ecology and the multiple use of forests in the Natural Resources Institute Finland and at the Department of Ecology, University of Oulu. She obtained her $\mathrm{PhD}$ in plant ecology at the University of Oulu in 1994. Her research covers a wide range of ecological and socio-ecological studies in terrestrial boreal and arctic ecosystems: nature tourism impacts, degradation and ecological restoration of peatlands and forests, the development of tools

to reconsolidate multiple land uses, and arctic vegetation responses to climate change. She is in the Board of Directors in the Society for Ecological Restoration (SER) and in the SER Europe Chapter. She has acted as the principal investigator in several projects funded by the EU (two LIFE projects, ERDF, EU Agricultural Fund, Interreg), the Academy of Finland, Nordic Forest Research Co-operation Committee, and private foundations. She has published over 60 papers registered in the Web of Science and over 40 other scientific papers or book chapters. 